\title{
"A Pall of Orthodoxy over the Classroom": Lessons from the Great Keyishian Case
}

\section{Marjorie Heins}

In Keyishian v. Board of Regents, the Supreme Court struck down a typical Cold War-era loyalty law that required administrators in New York State to investigate the political beliefs and associations of public employees, including teachers and professors, and to fire any who advocated "seditious" ideas or belonged to an organization with such aims. Justice William Brennan's majority opinion memorably proclaimed that academic freedom is "a special concern of the First Amendment, which does not tolerate laws that cast a pall of orthodoxy over the classroom." But the decision did not come until 1967, after twenty years in which the Court, for the most part, acquiesced in the sweeping political repression of the so-called McCarthy Era or else imposed only minor, technical limits on that era's massive denials of free speech and associational rights, not only in education but everywhere in public life.

That Keyishian came only after the Cold War Red Scare had dissipated suggests that courts are often unreliable protectors of civil liberties when they are needed most. What of other actors in the drama? Would more resistance on the part of teachers, unions, professional associations, and college administrators to the demands of legislative investigating committees and government loyalty programs have moderated the intensity and duration of the long nightmare known as McCarthyism? One thing I learned while researching and writing about Keyishian and other Cold War cases for my book Priests of Our Democracy: The Supreme Court, Academic Freedom, and the Anti-Communist Purge, is that resistance by college administrators, students, and teachers themselves might indeed have made a difference.

Keyishian was a challenge to New York State's 1949 Feinberg Law, which, unlike loyalty laws in some other states, did not require employees to swear a test oath abjuring certain beliefs or associations.

Marjorie Heins is the author of Priests of Our Democracy: The Supreme Court, Academic Freedom, and the Anti-Communist Purge and Ironies and Complications of Free Speech: News and Commentary from the Free Expression Policy Project, which she directed from 2001 to 2017. Between 1991 and 1998, she was head of the ACLU's Arts Censorship Project.

${ }^{1}$ Keyishian v. Board of Regents, 385 U.S. 589, 603 (1967). 
The five plaintiffs in Keyishian, teachers at the University of Buffalo, had never been communists and almost surely would not have been targeted by any antisubversive investigatory apparatus that the New York State University trustees might have created pursuant to the Feinberg Law. They became plaintiffs because the trustees, perhaps aiming to bypass the administrative burden of conducting individual investigations into the beliefs and associations of thousands of employees, decided to implement the Feinberg Law through a mandated test oath that required all employees either to deny past or present membership in the Communist Party or, if there had been such membership, to promise to tell the university president all about it (and presumably name others in the movement). The irony of Keyishian is that without the trustees' decision to impose this loyalty oath, the five plaintiffs, who refused on grounds of conscience to sign it, would not have lost, or been threatened with loss of, their jobs and thus would not have had a case to bring.

But would the trustees have backed off the test oath if there had been broader and more determined resistance from teachers and administrators at the University of Buffalo or, indeed, throughout the state college system? Hundreds of professors at Buffalo publicly opposed the oath, and some administrators did as well, more quietly. They understood that a test oath is not just some meaningless piece of paper: it is a forced ritual of conformity, a warning to educators confronted with it to keep their noses clean and certainly to anyone who harbored left-wing political sympathies, whether in the past or present, to avoid any outward manifestation of them.

Yet, unlike University of Chicago chancellor Robert Hutchins, who defended his faculty's intellectual freedom against Red Scare bullying by Illinois legislators in $1949,{ }^{2}$ the administrators at Buffalo did not resist the trustees' mandated oath, and despite protests from the faculty, including its chapter of the American Association of University Professors (AAUP), only five professors ultimately refused to sign. (Actually, four: the fifth, poet George Starbuck, was a library employee with a part-time appointment in the English Department, who refused to sign a similar statement on a civil service form.) Two of the plaintiffs, English professors Harry Keyishian and George Hochfield, firmly believed that if, instead of only five resisters, hundreds of faculty had had stood their ground and refused to sign, the trustees would have had to back down. As Keyishian reflected: "Suppose there had been twenty-five, or for that matter five hundred? Clearly, the problem would have been so serious that it is doubtful the

\footnotetext{
${ }^{2}$ Marjorie Heins, Priests of Our Democracy: The Supreme Court, Academic Freedom, and the Anti-Communist Purge (New York: New York University Press, 2013), 158-59.
} 
administration could have taken any action at all. The faculty underestimated its power and allowed itself to be stampeded into signing with unnecessary haste." 3 Hochfield thought that even a hundred refusers at Buffalo would have made the certificate unenforceable. ${ }^{4}$

An earlier oath controversy at the University of California casts some doubt on their certitude. In 1949, California's Red-hunting state senator Jack Tenney proposed seventeen antisubversive bills, including several requiring test oaths for various professions; doctors and lawyers resisted the pressure, but Robert Gordon Sproul, president of the University of California (UC), responded by instituting an oath that required all faculty to abjure belief in forceful overthrow of the government or membership in any organization with such a view. UC's Academic Senate vociferously protested, and three hundred professors refused to sign. Several resigned; eighteen who were fired eventually prevailed in court, but the victory was pyrrhic because the state legislature in 1950 mandated a test oath for all public employees, which remained in force until it was struck down seventeen years later, in the wake of the Supreme Court's decision in Keyishian. ${ }^{5}$

Yet the California resistance was not an exercise in futility. It was a collective act of conscience that energized others and continues to resonate in California academic history. Moreover, the California loyalty oath battle came relatively early in the Cold War Red Scare. By 1963, when staff at Buffalo were confronted with the "Feinberg Certificate," as it was euphemistically called, the perils and excesses of blacklists, Red-hunting legislative investigations, false accusations, and other forms of political demagoguery had become clear to most of the American public, and resistance would have had a better chance.

In fact, this is probably why Keyishian and Hochfield so firmly believed that widespread resistance on the part of the Buffalo faculty would have made a difference. Much had changed by the early 1960s; Keyishian and his fellow plaintiffs were of a different generation from the leftist professors of the fifties who were, for the most part, not only persecuted by administrators but shunned and abandoned by their fellow academics. Within a few years, students would be loudly protesting in loco parentis rules and, often with the support of faculty, would

${ }^{3}$ Harry Keyishian, unpublished paper, (1965), 13 (in the author's files). The national AAUP, by contrast, helped Keyishian and his fellow plaintiffs with legal expenses.

${ }^{4}$ George Hochfield, telephone interview by author, Feb. 6, 2011.

${ }^{5}$ Ellen Schrecker, No Ivory Tower: McCarthyism and the Universities (New York: Oxford University Press, 1986), 117-25; and Vogel v. County of Los Angeles, 68 Cal. 2d 18 (1967). 
become increasingly active in the civil rights movement and in opposing the Vietnam War.

The four years between 1963, when the Feinberg Certificate was first imposed on a reluctant University of Buffalo faculty, and 1967, when the Supreme Court decided the Keyishian case, are also significant. While McCarthyism was certainly crumbling by 1963 , Cold War demonization of communism was still very much the dominant ideology. By 1967, administrators (and judges) could at least feel secure that if they stood up for professors who objected to loyalty investigations and oaths, they would not be immediately excoriated as fellow travelers and "pinkos," although, even in 1967, there was plenty of angry political backlash to the Keyishian decision.

Loyalty oaths are not a big issue on campus today, except for the occasional dustup when a principled person, often a Quaker, refuses to sign one. Today, groups such as Campus Watch and Professor Watchlist spearhead new-style attempts to silence opinions they disfavor on campus, and virulent, sometimes violent, threats and harassment against professors with views contrary to the harassers' have become increasingly common. ${ }^{6}$

Probably the major academic freedom issue today, however, because it is the most pervasive, does not appear at first to be about academic freedom at all. Over the past quarter century, the structure of US higher education has changed, with dramatic increases in topdown management and corresponding decreases in tenured and tenure-track faculty positions. Seventy percent of faculty jobs today are filled by an underpaid army of adjuncts and other contingent and contract workers. ${ }^{7}$ Their precarious status has grave implications for all aspects of academic freedom: research, writing, teaching, participation in governance, and so-called extramural activity-political engagement in the world outside campus.

In 1915, when the AAUP was created in response to firings of professors for their political activity (usually support of labor organizing), it created a Committee A on Academic Freedom and Tenure. The two were thought inseparable; that is, without the security of tenure, faculty could not be expected to exercise any aspect of academic freedom, for fear of losing their jobs. The AAUP was organized by high-status,

\footnotetext{
${ }^{6}$ See, for example, Hans-Joerg Tiede, "Exhuming McCarthy (Meet Me at the Book Burning)," Academe 103, no. 5 (Sept.-Oct. 2017), 15-19; Academe 103, no. 6 (Nov.Dec. 2017), https://www.aaup.org/issue/november-december-2017; and "Targeted Harassment of Faculty," American Association of University Professors, https:// onefacultyoneresistance.org/faculty-attack-fighting-targeted-harassment/.

${ }^{7}$ AAUP, "Visualizing Change: The Annual Report on the Economic Status of the Profession, 2016-17,"Academe 103, no. 2 (March-April 2017), 7, https://www.aaup. org/report/visualizing-change-annual-report-economic-status-profession-2016-17.
} 
tenured professors from elite universities and continued to have that character for much of the twentieth century. ${ }^{8}$ For a number of reasons, by the last decades of the century, the AAUP had lost thousands of members as well as advocacy chapters on many campuses. Were tenured and tenure-track teachers feeling too secure? Were there just fewer of them? The AAUP has survived by becoming largely an association of labor unions (collective bargaining units) on state college campuses. The Supreme Court's regrettable 1980 ruling in National Labor Relations Board v. Yeshiva University, ${ }^{9}$ holding that faculty are part of management and, therefore, cannot collectively organize into unions, has prevented faculty union organizing on most private campuses, although this is beginning to change with the NLRB's recognition that most professors today have no significant management role.

Faculty unions fight not only for basic economic rights but also for academic freedom, a value enshrined in most faculty handbooks but often ignored by administrators. The AAUP has evolved a long way from its elitist roots and now works hard to protect academic freedom for all faculty, whether or not tenured or tenure-track. But AAUP chapters do not even exist at many of our major universities, and there remains a sense of privilege among the shrinking ranks of tenured/tenure-track teachers, an exclusion of contingent faculty from important meetings and decisions, and a reluctance to see contingent faculty as full colleagues. The result is that administrators can exercise ever more control over decisions about academic policy and curriculum, decisions once acknowledged as faculty prerogatives. A striking example is the spread of global campuses, such as New York University's branches in Abu Dhabi and Shanghai or Yale-National University of Singapore, whose programs were envisioned, planned, and created by administrators with essentially no faculty involvement, and despite serious concerns about locating supposedly liberal educational institutions in authoritarian states. ${ }^{10}$

Beyond this overwhelming structural challenge, other pressing academic freedom issues today include speech codes that, in broad

\footnotetext{
${ }^{8}$ Richard Hofstadter and Walter Metzger, The Development of Academic Freedom in the United States (New York: Columbia University Press, 1955).

${ }^{9}$ NLRB v. Yeshiva University, 444 U.S. 672 (1980).

${ }^{10}$ Eric Weinberger, "Why Is Yale Outsourcing a Campus to Singapore?" The Atlantic, Oct. 27, 2011, https://www.theatlantic.com/national/archive/2011/10/ why-is-yale-outsourcing-a-campus-to-singapore/247463/; Joan Bertin, Marjorie Heins, Cary Nelson, and Henry Reichman, "An Open Letter from the AAUP to the Yale Community," Oct. 4, 2012, AAUP, https://www.aaup.org/news/2012/ open-letter-aaup-yale-community; and Sophie Gould, "New AAUP Chapter to Push Shared Governance," Yale Daily News, Oct. 12, 2012, https://yaledailynews. $\mathrm{com} / \mathrm{blog} / 2012 / 10 / 12 /$ new-aaup-chapter-to-push-shared-governance.
} 
and vague terms, restrict what teachers and students can say in the classroom or elsewhere on campus; questions about where to draw the line between sexual or racial harassment and robust, protected free speech; and speaking invitations to those with far-right and racist views. Space limitations preclude exploring these issues here. Suffice it to say that each one is intricate and tricky, and requires careful balancing. But none is a structural problem that calls so urgently for advocacy and organizing - including union organizing - in order to defend the principles of academic freedom that are fundamental to the endangered enterprise we call higher education.

doi: $10.1017 /$ heq.2018.18

\section{"Friendly Public Sentiment" and the Threats to Academic Freedom}

\section{Timothy Reese Cain}

Historians frequently trace the modern era of academic freedom to late nineteenth century changes in the rising universities, with many citing the Henry Carter Adams case as the first of its type in US higher education. ${ }^{1}$ Adams lost his half-time faculty position at Cornell University when his 1886 speech in support of labor offended lumber magnate Henry Sage, the powerful chairman of the institution's governing board. The case contained many elements that can be found in modern academic freedom struggles, but the first thing I think about when considering the case is an exchange of letters between Adams and James Burrill Angell, president of the University of Michigan. Adams had a concurrent temporary part-time appointment at Michigan, but his

Tim Cain (tcain@uga.edu) is an Associate Professor at the University of Georgia's Institute of Higher Education. His recent and forthcoming publications include articles in Labor: Studies in Working-Class History and Perspectives on the History of Higher Education; chapters in edited volumes on adjunct unionization, the history of student life, and assessment; and Campus Unions: Organized Faculty and Graduate Students in US Higher Education (2017).

${ }^{1}$ See, for example, Mary O. Furner, Advocacy and Objectivity: A Crisis in the Professionalization of American Social Science, 1865-1905 (Lexington: University Press of Kentucky, 1975). 